\title{
Energia e ambiente
}

$\mathrm{A}$

EDIÇÃO do número 102 de ESTUDOS AVANÇADOS ${ }^{1}$ compreende três dossiês. Presente no debate contemporâneo internacional, o primeiro trata de "Energia e ambiente", cujas múltiplas facetas propõem questões estratégicas para o desenvolvimento sustentável. Guardada a complexidade de que as relações entre energia e ambiente suscitam, esse dossiê aborda problemas que vêm mobilizando a atenção da comunidade científica, quando menos da opinião pública informada. Entre os problemas, cuida-se de explorar o monitoramento da qualidade do ar no Brasil; as preocupações com a infraestrutura verde para minimizar os impactos da poluição atmosférica; os recursos hídricos como forma de integração regional e transfronteiriça; os cenários atuais da energia eólica; os efeitos ambientais de operações urbanas; os dilemas e desafios inerentes ao futuro da diversidade; e ainda, os desígnios da ecologia política sob a perspectivas das populações indígenas. Parte dos artigos tem por foco estudo de casos, sugestivos de tendências mais abrangentes que estejam em curso no domínio dessas relações.

O segundo dossiê, "Híbridos do conhecimento", reúne artigos propostos pelo grupo de pesquisa Ambiente e Sociedade do Instituto de Estudos Avançados da USP. O propósito desse dossiê é promover a integração entre diferentes campos do conhecimento sob perspectivas de codesign, coprodução e codisseminação. $\mathrm{O}$ conjunto de artigos guarda intercâmbio com o dossiê anterior, já que aborda também temas como biodiversidade; qualidade e distribuição da água; governança dos recursos hídricos; geração e distribuição de energia; além de outros como alterações nos oceanos e respostas às mudanças climáticas. A abordagem desses temas tem em comum o foco na multiplicidade de atores, de interesses e de disputas, o que possibilita avaliar impactos no agravamento das desigualdades sociais e nos impasses às garantias de direitos humanos para o maior número de cidadãos e cidadãs. Ao mesmo tempo, essas abordagens metodológicas, sistêmicas e interativas, permitem conhecer e avaliar experimentos e inovações em curso, acenando para um futuro mais sustentável e adaptado à escassez de recursos no contexto de mudanças ambientais globais.

O terceiro dossiê, "Espaços religiosos", resulta de seminário realizado no IEAUSP em novembro de 2019, promovido pelo grupo de pesquisa do IEA, voltado para estudos sobre memória e preservação do patrimônio cultural, artístico e científico no Brasil. O balanço dos estudos atuais acerca do patrimônio histórico-artístico conservado em espaços religiosos e institucionais católicos no Brasil constitui-se no objetivo desse dossiê. Alguns aspectos mereceram atenção especial, como as heranças coloniais construídas a partir das simbioses entre culturas africanas e indígenas e os modelos europeus; o surgimento de acervos públicos de arte sacra no curso da formação das grandes cidades e metrópoles; os novos modelos decorativos e arquitetônicos, procedentes da Escola da Abadia Beneditina de Beuron. Esses temas são igualmente contemplados em artigos que iluminam casos determinados, como o patrimônio jesuítico de Rio de Janeiro e de São Paulo, e ainda que exploram o catolicismo negro na São Paulo do século XIX.

Nota

l Para saber mais sobre Estudos Avançados, consultar Bosi (2011).

Referência

BOSI, A. A revista Estudos Avançados, Estudos Avancados, v.25, n.73, p.155-58, 2011. Disponível em: <https://www.scielo.br/scielo.php?script=sci_arttext\&pid=S0103-40142011000300019\&lng= pt\&nrm=iso\&tlng=pt>.

Sergio Adorno ${ }^{\mathrm{I}}$

I Universidade de São Paulo, Faculdade de Filosofia, Letras e Ciências Humanas, São Paulo, Brasil. @-sadorno@usp.br / https://orcid.org/0000-0002-5358-1289. 